\title{
Computational analysis of hybrid perovskite on silicon 2-T tandem solar cells based on a Si tunnel junction
}

\author{
Alain Rolland ${ }^{1} \cdot$ Laurent Pedesseau $^{1} \cdot$ Mickaël Kepenekian $^{2} \cdot$ \\ Claudine Katan' ${ }^{2}$ Yong Huang ${ }^{1}$ - Shijian Wang ${ }^{1}$ Charles Cornet $^{1}$ • \\ Olivier Durand ${ }^{1} \cdot$ Jacky Even $^{1}$
}

Received: 30 August 2017/ Accepted: 13 December 2017

(C) Springer Science+Business Media, LLC, part of Springer Nature 2017

\begin{abstract}
In this study, the optoelectronic properties of a monolithically integrated 2 terminals tandem solar cell are simulated with a particular emphasis on the role of a tunnel junction in silicon. Following the large success of low-cost hybrid organic-inorganic perovskites solar cells, the possibility of using perovskites as absorbers in silicon based tandem solar cells is estimated. The top sub-cell consists in methyl ammonium mixed bromide-iodide lead perovskite, $\mathrm{CH}_{3} \mathrm{NH}_{3} \mathrm{PbI}_{3(1-\mathrm{x})} \mathrm{Br}_{3 \mathrm{x}}(0 \leq \mathrm{x} \leq 1)$, while the bottom subcell is made by a single-crystalline silicon bottom sub-cell. A Si-based tunnel junction is used to connect the two sub-cells in series. Numerical simulations are based on a onedimensional numerical drift-diffusion model. It is shown that a perovskite layer with $20 \%$ of bromide and a thickness in the range of 300-400 nm can afford current matching with the silicon bottom cell. Good interconnection between single cells is ensured by standard $n$ and $\mathrm{p}$ doping levels beyond $5 \times 10^{19} \mathrm{~cm}^{-3}$ in the tunnel junction. A maximum efficiency of $27 \%$ is predicted for the tandem cell, which exceeds the efficiencies of the individual solar cells of silicon $(17.3 \%)$ and perovskite $(17.9 \%)$.
\end{abstract}

Keywords Perovskites · Tandem solar cells · Tunnel junction · Monolithic integration on silicon

This article is part of the Topical Collection on Numerical Simulation of Optoelectronic Devices, NUSOD' 17.

Guest edited by Matthias Auf der Maur, Weida Hu, Slawomir Sujecki, Yuh-Renn Wu, Niels Gregersen, Paolo Bardella.

Alain Rolland

alain.rolland@univ-rennes1.fr

$1 \quad$ INSA de Rennes, UMR 6082, CNRS, Fonctions Optiques pour les Technologies de l'Information (FOTON), 35708 Rennes, France

2 CNRS, Ecole Nationale Supérieure de Chimie de Rennes, INSA de Rennes, UMR 6226, Institut des Sciences Chimiques de Rennes (ISCR), Université de Rennes 1, 35042 Rennes, France 


\section{Introduction}

In order to ensure a large part of the worldwide energy production, photovoltaics has to increase its watt produced over price ratio and match, if not exceed, the one of nuclear and fossil energies. In recent years, two strategies have emerged from this objective. The first path consists in increasing significantly the solar-cell efficiencies. In that sense, one solution is to develop group III-V multi-junction solar cells (MJSC), which combine absorbers with different bandgap energies allowing to harvest a wider range of solar spectrum while lowering intrinsic losses such as thermalisation losses (Chen et al. 2015; Hirst and Ekins-Daukes 2011), and can therefore surpass the well-known SchockleyQueisser limit of an ideal single-junction solar cell (Shockley and Queisser 1961). Such multigap systems have achieved conversion efficiencies exceeding 40\% (Dimroth et al. 2014). However, these MJSC are currently developed on expensive GaAs and Ge substrates and required high-quality materials, which incurs a substantial associated cost. Targeting terrestrial applications, less expensive alternatives have been proposed with two junction terminal cells containing a $\mathrm{Si}$ bottom sub-cell, and developed on a low-cost $\mathrm{Si}$ substrate (Kurtz et al. 1990; Liu et al. 2013; Loper et al. 2014, 2015; Durand et al. 2014; Filipič et al. 2015; Bailie et al. 2015; Green et al. 2016; Bush et al. 2017). For a Si bottom sub-cell with a bandgap of $1.12 \mathrm{eV}$, it has been shown that the maximum conversion efficiency are achieved with a top sub-cell bandgap lying between 1.6 and $1.8 \mathrm{eV}$ (Coutts et al. 2002; Geisz and Friedman 2002; Almosni et al. 2013).

Following a different strategy, hybrid organic-inorganic perovskite (HOP) materials, such as lead methyl ammonium tri-iodide $\mathrm{CH}_{3} \mathrm{NH}_{3} \mathrm{PbI}_{3}$, in so-called 'perovskite cells' have recently attracted huge attention (Kojima et al. 2009; Lee et al. 2012; Liu et al. 2013; Burschka et al. 2013; Jeon et al. 2015; Minemoto and Murata 2015; Tsai et al. 2016; Blancon et al. 2017). Not only have these solar cells demonstrated remarkably high efficiencies (around 20\%) and high open-circuit voltages $\left(\mathrm{V}_{\mathrm{oc}}\right.$ ) (Snaith 2013), but also they offer great potential for low costs of production. Taking advantage of both these strategies, perovskites are ideal candidates as a top sub-cell absorber for tandem cells built on CIGS or Si due to their high radiative recombination efficiencies, excellent absorption and charge transport characteristics and their broad ability to tune the bandgap (Bailie et al. 2015; Mailoa et al. 2015; Albrecht et al. 2015). The current record for a two terminal perovskite tandem cell is obtained with a perovskite-silicon tandem cell at $23.6 \%$ (Green et al. 2016; Bush et al. 2017).

As already widely developed in the III-V multigap systems (Geisz et al. 2008; Baudrit and Algora 2008; Friedman 2010; Rolland et al. 2014), our approach to connect electrically both subcells is to use a tunnel junctions (TJ), or Esaki diode (Esaki 1958), placed between them. An all-Si made interband TJ offers a low resistance behavior due to the high doping values reachable in $\mathrm{Si}$ (Bailie et al. 2015; Mailoa et al. 2015).

Simulations of perovskite-based solar cells are a key point in the optimization of the device architecture (Minemoto and Murata 2014, 2015; Hörantner and Snaith 2017). As a major feature, the behavior of photo-carriers in HOP materials can be dealt with in the same way than in inorganic materials (Minemoto and Murata 2015). This similarity enables the use of existing drift-diffusion based device simulator widely used in the context of conventional semiconductors.

In this work, we conduct numerical simulations of two-terminal tandem cells based on HOP materials as top sub-cell absorber monolithically integrated on a bottom Si sub-cell. The sub-cells are electrically connected through a low-resistance TJ. As it has recently been shown that introducing a mixture of bromide and iodide in the halide composition of 
lead methyl ammonium perovskites allows for tuning the band gap (Sadhanala et al. 2014), we chose $\mathrm{CH}_{3} \mathrm{NH}_{3} \mathrm{PbI}_{3(1-\mathrm{x})} \mathrm{Br}_{3 \mathrm{x}}$ as top sub-cell absorber material. Besides halide concentration, the thickness of the absorber will also influence the overall performances of the total cell. Our computational study allows us to design an optimal HOP based tandem cell. The best efficiency is obtained for a bromide ratio $\mathrm{x}=0.2$ and a thickness of the HOP layer between 300 and $400 \mathrm{~nm}$. In these conditions the tandem cell exhibits a conversion efficiency of $27 \%$ higher than the efficiencies of the Top and Bottom sub-cell which are respectively 17.9 and $17.3 \%$. The Hoke effect under light soaking is also mentioned and alternative materials designed to limit or avoid such bromide/iodide segregation are briefly discussed.

\section{Device structure and simulation method}

Simulations are performed using the Silvaco Atlas device simulator (Silvaco Inc. 2012), which allows to numerically solve Poisson's equation coupled with the continuity equations for both electrons and holes under steady state conditions. It is possible to account for quantum effects, which are mandatory to simulate a TJ. Different levels of mesh are required for tandem cell devices in order to consider different layer thicknesses that vary from tens of nanometers to hundreds of micrometers in realistic devices. Figure 1 shows a scheme of a perovskite tandem solar cell monolithically integrated on a $n$-doped silicon substrate. The structure consists in a $850 \mathrm{~nm}$ thick hole transport material (HTM) layer, a $\mathrm{CH}_{3} \mathrm{NH}_{3} \mathrm{PbI}_{3(1-\mathrm{x})} \mathrm{Br}_{3 \mathrm{x}}$ absorbing layer of various thickness, and a $300 \mathrm{~nm}$ thick $\mathrm{TiO}_{2}$ electron transport layer. The $2 \times 20 \mathrm{~nm}$ thick $\mathrm{Si}\left(n^{++}\right) / \mathrm{Si}\left(p^{++}\right)$TJ insures the electrical connection between the two subcells. Finally, a $280 \mu \mathrm{m}$ thick $n$-type $\mathrm{Si}$ substrate $\left(\mathrm{N}_{\mathrm{D}}=10^{16} \mathrm{~cm}^{-3}\right)$ includes deep trap levels, with an energy level located at $0.5 \mathrm{eV}$ above

Fig. 1 Overview of the structure showing the different layers taken into account in the simulation

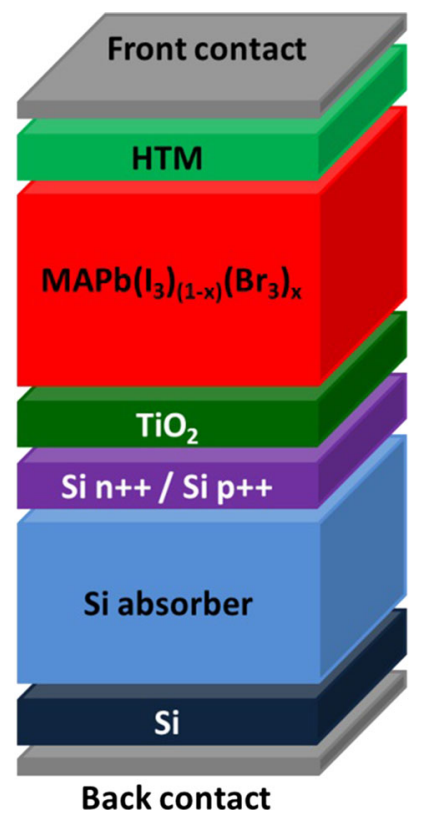


the valence band edge and a density corresponding to a diffusion length of $600 \mu \mathrm{m}$, and a $100 \mathrm{~nm}$ thick $n^{++} \mathrm{Si}$ layer $\left(\mathrm{N}_{\mathrm{D}}=10^{19} \mathrm{~cm}^{-3}\right)$ for the back contact.

It is not obvious to define relevant values of the physical parameters needed to accurately simulate the total cell, particularly for the HOP materials since their growth procedures are not yet standardized. Table 1 summarizes the physical key parameters from the literature used in this study for $\mathrm{HTM}, \mathrm{HOP}, \mathrm{TiO}_{2}$ and $\mathrm{Si}$ materials (Noh et al. 2013; Minemoto and Murata 2014, 2015). Following the work by Minemoto and Murata (2015), HOP electron $\left(\mu_{\mathrm{n}}\right)$ and hole $\left(\mu_{\mathrm{p}}\right)$ mobilities are set to $2 \mathrm{~cm}^{2} \mathrm{~V}^{-1} \mathrm{~s}^{-1}$. HOP materials are assumed to be $n$-type with a low doping level of $10^{13} \mathrm{~cm}^{-3}$. Deep traps are also considered with an energy level located $0.5 \mathrm{eV}$ below the conduction band edge and a density $\mathrm{N}_{\mathrm{T}}=10^{15} \mathrm{~cm}^{-3}$ (Stranks et al. 2013; Yang et al. 2015), which corresponds to a carrier diffusion length of about $700 \mathrm{~nm}$ in good agreement with available experimental data (Stranks et al. 2013; Minemoto and Murata 2015).

The imaginary part of the refractive index $\mathrm{k}$ for $\mathrm{HTM}, \mathrm{TiO}_{2}$ and $\mathrm{CH}_{3} \mathrm{NH}_{3} \mathrm{PbI}_{3(1-\mathrm{x})} \mathrm{Br}_{3 \mathrm{x}}$ layers was calculated from the absorption coefficient given by $\alpha=A \sqrt{\left(E-E_{g}\right)}$ where $\mathrm{A}$ is a prefactor, $\mathrm{E}_{\mathrm{g}}$ the material bandgap energy, and $k=\frac{1.24 \alpha}{4 \pi E}$ (with $\alpha$ in $\mathrm{cm}^{-1}$ and $E=h v$ in $\mathrm{eV}$ ). A is kept constant for all the subsequently considered materials. In the work by Minemoto and Murata (2015), A amounts to $10^{5} \mathrm{~cm}^{-1} \mathrm{eV}^{-1 / 2}$. Here, we chose $2.5 \times 10^{5} \mathrm{~cm}^{-1} \mathrm{eV}^{-1 / 2}$, which leads to a better agreement with the experimental absorption coefficient reported in ref. (Ball et al. 2015). In this work, the real part of the refractive index is kept constant for the whole wavelength range of the solar spectra: $\mathrm{n}=2.54$ : average value of $\mathrm{n}$ published in ref. (Ball et al. 2015).

In addition to the thickness of the absorber, one essential parameter of a tandem cell is the bandgap of the light absorbing material. Here, the choice of $\mathrm{CH}_{3} \mathrm{NH}_{3} \mathrm{PbI}_{3(1-\mathrm{x})} \mathrm{Br}_{3 \mathrm{x}}$ mixed halide allows to introduce a wide range of bandgaps from $1.55 \mathrm{eV}(\mathrm{x}=0)$ to $2.3 \mathrm{eV}$ $(\mathrm{x}=1)$. Bandgap energies and electron affinities of mixed compositions were computed from linear interpolations of the values reported for the pure tri-iodide and tri-bromide compounds (Table 1). In the following we monitor the tandem cell efficiencies for various bromide concentrations and various absorbing layer thicknesses.

Table 1 Input parameters for device simulation

\begin{tabular}{lllll}
\hline Parameter & $\mathrm{CH}_{3} \mathrm{NH}_{3} \mathrm{PbI}_{3(1-\mathrm{x})} \mathrm{Br}_{3 \mathrm{x}}$ & $\mathrm{HTM}$ & $\mathrm{TiO}_{2}$ & $\mathrm{Si}$ \\
\hline $\mathrm{E}_{\mathrm{g}}(\mathrm{eV})$ & $1.55+0.75 \mathrm{x}$ & 3.0 & 3.2 & 1.12 \\
$\chi(\mathrm{eV})$ & $3.9-0.55 \mathrm{x}$ & 2.45 & 3.9 & 4.17 \\
$\varepsilon_{\mathrm{r}}$ & 6.5 & 3.0 & 9 & 11.8 \\
$\mu_{\mathrm{n}} / \mu_{\mathrm{p}}\left(\mathrm{cm}^{2} \mathrm{~V}^{-1} \mathrm{~s}^{-1}\right)$ & $2 / 2$ & $2 \times 10^{-4} / 210^{-4}$ & $20 / 10$ & $1500 / 480$ \\
$\tau_{\mathrm{n}} / \tau_{\mathrm{p}}(\mathrm{s})$ & $10^{-6 / 10^{-6}}$ & $10^{-7} / 10^{-7}$ & $10^{-7} / 10^{-7}$ & $10^{-4} / 10^{-4}$ \\
$\mathrm{~N}_{\mathrm{C}}\left(\mathrm{cm}^{-3}\right)$ & $2.2 \times 10^{18}$ & $2.2 \times 10^{18}$ & $2.2 \times 10^{18}$ & $2.8 \times 10^{19}$ \\
$\mathrm{~N}_{\mathrm{V}}\left(\mathrm{cm}^{-3}\right)$ & $1.8 \times 10^{19}$ & $1.8 \times 10^{19}$ & $1.8 \times 10^{19}$ & $1.04 \times 10^{19}$ \\
$\mathrm{~N}_{\mathrm{A}}\left(\mathrm{cm}^{-3}\right)$ & - & $210^{18}$ & - & - \\
$\mathrm{N}_{\mathrm{D}}\left(\mathrm{cm}^{-3}\right)$ & $10^{13}$ & - & $10^{16}$ & - \\
\hline
\end{tabular}

$\mathrm{N}_{\mathrm{A}}$ and $\mathrm{N}_{\mathrm{D}}$ are the acceptors and donors doping concentrations, $\mathrm{N}_{\mathrm{C}}$ and $\mathrm{N}_{\mathrm{V}}$ are the effective densities of states in the conduction and valence band, $\varepsilon_{\mathrm{r}}$ the relative permittivity, $\chi$ the electron affinity, $\mathrm{E}_{\mathrm{g}}$ the bandgap energy, $\mu_{\mathrm{n}}$ and $\mu_{\mathrm{p}}$ the electron and hole mobility, and $\tau_{\mathrm{n}}$ and $\tau_{\mathrm{p}}$ the electron and hole lifetime 


\section{Effect of absorber layer bandgap energy and thickness}

\subsection{The current matching issue in the HOP/Si tandem cell}

In this section, we show that a good current matching between the Top and Bottom subcells is required to obtain a maximum efficiency of the tandem cell. Figure 2 shows the simulated current-voltage characteristics $(\mathrm{J}-\mathrm{V})$ of the top HOP sub-cell (with $\mathrm{x}=0.2$ ), the bottom silicon sub-cell and the HOP-based tandem cell under AM1.5 illumination. The doping level of the silicon TJ is fixed at $10^{20} \mathrm{~cm}^{-3}$.

The results are in good agreement with the literature (Kojima et al. 2009; Lee et al. 2012; Liu et al. 2013; Burschka et al. 2013; Masuko et al. 2014; Jeon et al. 2015; Minemoto and Murata 2015). The efficiencies of the silicon bottom cell, and of the HOP cell for $\mathrm{x}=0.2$, are 17.3 and $17.9 \%$ respectively. For the tandem cell, the open-circuit voltage is $\mathrm{V}_{\mathrm{OC}}=1.56 \mathrm{~V}$, which corresponds to the sum of the open-circuit voltages of each sub-cell. On the other hand, the same short-circuit current value than for the top cell is obtained, which is the maximum of the total current that can be reached in the tandem cell. It shows that in this device the current limitation is mainly due to the HOP top sub-cell which leads to a non-ideal current matching between top and bottom sub-cells.

It is known that the bandgap energy of the top sub-cell absorber material and the thickness of the absorbing layer are key parameters to obtain a good current matching between the two sub-cells (Geisz et al. 2008). Figure 3 shows the band diagram of the tandem cell at room temperature and at thermal equilibrium for various halide compositions. Due to the low residual doping level of the HOP material, the absorbing layer acts almost as an intrinsic layer and the top sub-cell can be considered as a PIN junction. Moreover, whatever the halide composition, when an electron-hole pair is created in the perovskite layer, the electrons will easily flow to the $\mathrm{TiO}_{2}$ layer without encountering any potential barrier. The behavior of the holes is similar from the perovskite layer to HTM layer.

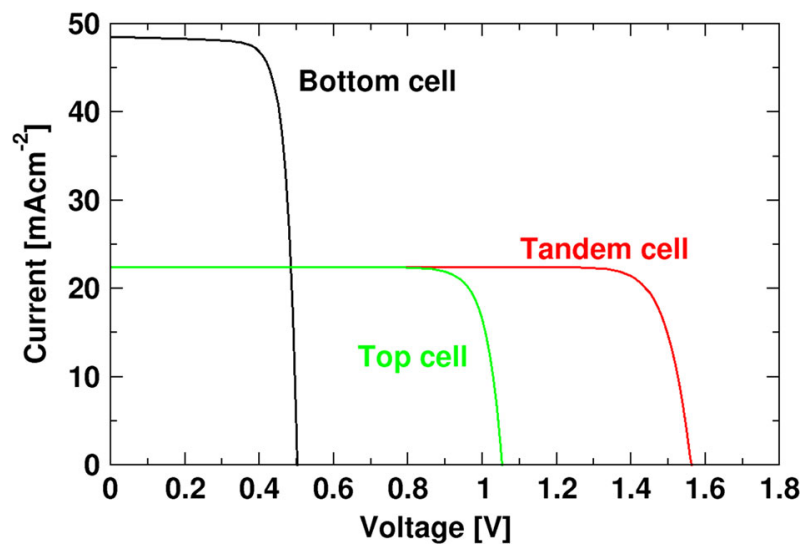

Fig. $2 \mathrm{~J}-\mathrm{V}$ characteristics of the bottom cell (silicon absorber, black line), top cell (HOP absorber, green line) and tandem cell (silicon and HOP absorbers, red line) under AM1.5 illumination. The HOP absorber material is $\mathrm{CH}_{3} \mathrm{NH}_{3} \mathrm{PbI}_{3(1-\mathrm{x})} \mathrm{Br}_{3 \mathrm{x}}$ with $\mathrm{x}=0.2$ and a thickness of $300 \mathrm{~nm}$. (Color figure online) 


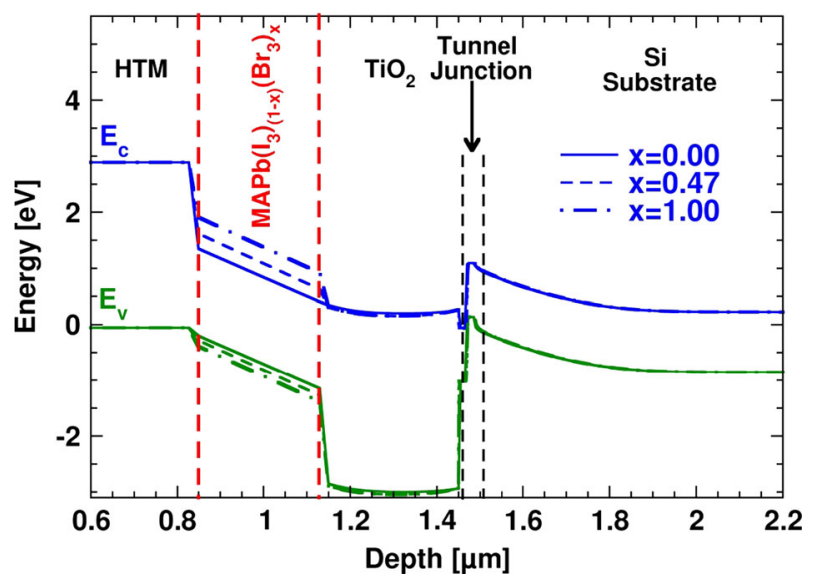

Fig. 3 Energy Band diagrams of the tandem cell. The valence and conduction band edges (resp. $E_{V}$ and $E_{C}$ ) are depicted in green and blue, respectively. The position of the top cell is highlighted between red dash lines. Effect of halide composition in the $\mathrm{HOP}$ absorber $\mathrm{CH}_{3} \mathrm{NH}_{3} \mathrm{PbI}_{3(1-\mathrm{x})} \mathrm{Br}_{3 \mathrm{x}}$ is illustrated for $\mathrm{x}=0.0$ (solid line), 0.47 (dashed line) and 1.0 (dashed dotted line). The thickness is kept constant at $300 \mathrm{~nm}$. (Color figure online)

\subsection{Optimization of the HOP single cell}

In order to validate our simulation, the influence of the absorbing layer bandgap and of its thickness on the HOP cell efficiency is examined, and the theoretical results are compared to published experimental data.

Figure 4 shows the mapping of $\mathrm{J}_{\mathrm{SC}}, \mathrm{V}_{\mathrm{OC}}$ and $\mathrm{E}_{\mathrm{ff}}$ as a function (1) of the bromide concentration in the absorbing layer, and (2) of its thickness in a HOP solar cell. For a given thickness, the short circuit current $\mathrm{J}_{\mathrm{SC}}$ decreases when the bandgap energy increases because the amount of photo-generated carriers decreases. Concurrently, the open circuit voltage $\mathrm{V}_{\mathrm{OC}}$ increases. These contradictory trends lead to an optimum for the top sub-cell efficiency which is currently obtained for an absorber bandgap energy of about $1.4 \mathrm{eV}$ (Dimroth 2006). From our simulations, we find a maximum efficiency around $18.5 \%$ obtained for $\mathrm{CH}_{3} \mathrm{NH}_{3} \mathrm{PbI}_{3}$ with a layer thickness between 300 and $500 \mathrm{~nm}$. With a similar thickness we find an efficiency of $11.3 \%$ for the $\mathrm{CH}_{3} \mathrm{NH}_{3} \mathrm{PbBr}_{3}$ compound. These values compare well with the corresponding experimentally measured efficiencies of $17 \%\left(\mathrm{CH}_{3} \mathrm{NH}_{3} \mathrm{PbI}_{3}\right)$ (Im et al. 2014) and 9\% $\left(\mathrm{CH}_{3} \mathrm{NH}_{3} \mathrm{PbBr}_{3}\right)(\mathrm{Chen}$ et al. 2014; Sheng et al. 2015) and show that our simulation is well suitable for further study of the HOP tandem cell.

\subsection{Silicon tunnel junction}

The silicon tunnel junction used to interconnect both top and bottom sub-cell plays an important role and behaves as a short circuit when the tandem-cell operates (Baudrit and Algora 2008, 2010; Rolland et al. 2014). Therefore, in order to optimize the whole device, the knowledge of the minimum doping level of the $n^{++}$and $p^{++}$region of this junction for efficient band to band tunneling effect is mandatory. To approximately calculate the tunneling current, an elastic model for interband tunneling is used and the resullting current is given by: 


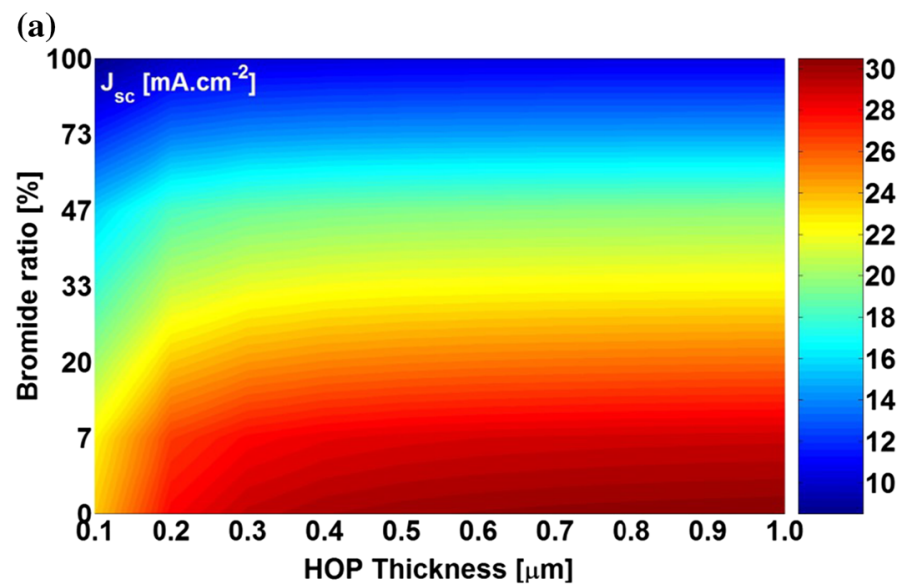

(b)
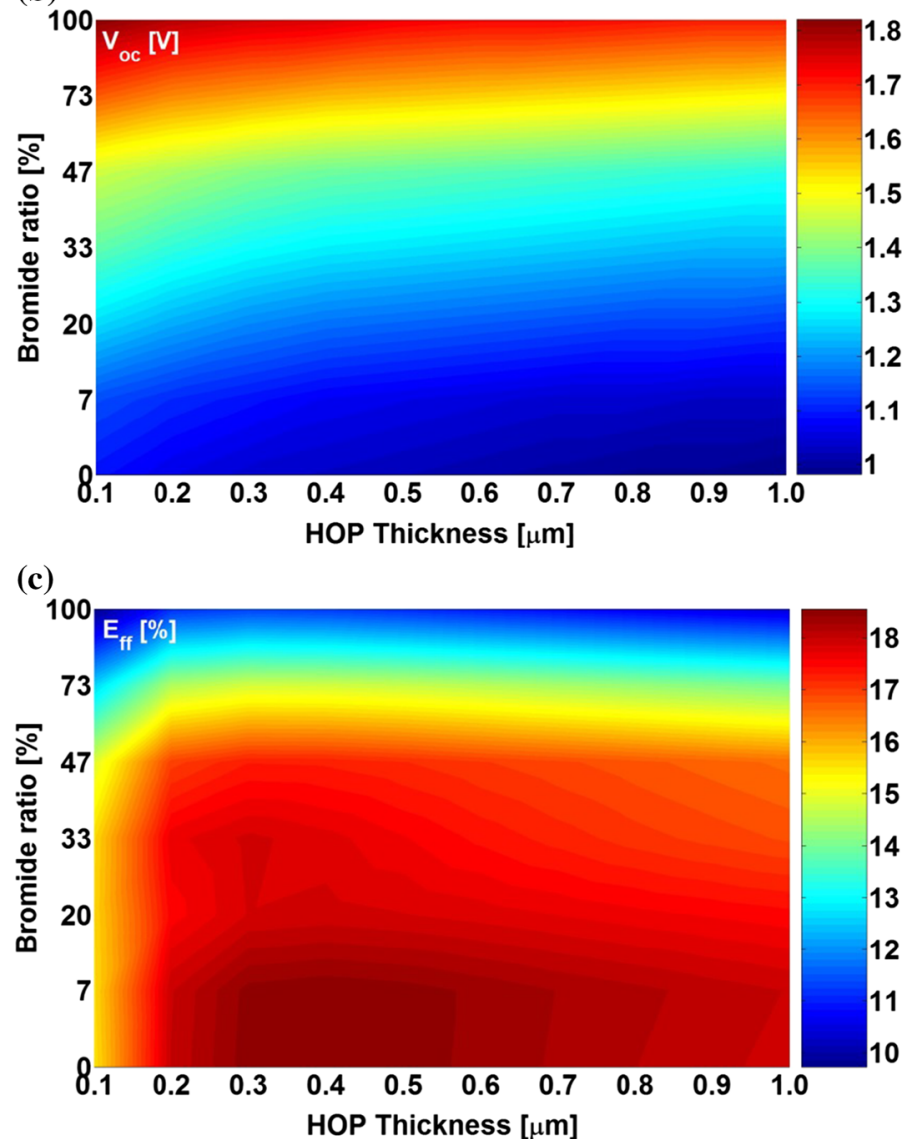

Fig. 4 HOP top cell a short-circuit current $J_{\mathrm{sc}}$, b open-circuit voltage $\mathrm{V}_{\mathrm{oc}}$, and $\mathbf{c}$ efficiency $\mathrm{E}_{\mathrm{ff}}$ 


$$
J_{T}=\frac{q k T}{2 \pi^{2} h^{3}} \sqrt{m_{e} m_{h}} \int_{E} T(E) \ln \left(\frac{1+\exp \left(\frac{E_{F, r}-E}{k T}\right)}{1+\exp \left(\frac{E_{F, l}-E}{k T}\right)}\right) d E
$$

where $J_{T}$ is the tunneling current, $h$ is Planck constant, and $m_{e}\left(m_{h}\right)$ is the electron (hole) effective mass. $\mathrm{J}_{\mathrm{T}}$ is evaluated for all energies at which tunneling is possible, up to the maximum of the band energy at the interface. $\mathrm{T}(\mathrm{E})$ is the tunneling probability which is given by the WKB approximation (Silvaco Inc. 2012). $\mathrm{E}_{\mathrm{F}, \mathrm{r}}$ and $\mathrm{E}_{\mathrm{F}, \mathrm{l}}$ are the quasi-Fermi levels on the right and left side of the tunnel junction respectively. $\mathrm{J}_{\mathrm{T}}$ is converted into a recombination rate and inserted into the current continuity equation at each end of the tunneling paths.

Figure 5 shows the variation of the tunnel junction peak current and the differential negative resistance, which is representative of the peak-valley current ratio, as a function of the doping level of each region. The doping level is assumed to be the same on both side of the junction. A variation of more than six orders of magnitude is observed for an increase of the doping level from $3 \times 10^{19}$ to $10^{20} \mathrm{~cm}^{-3}$. For the latter value, the reverse tunnel junction current is greater than $10^{5} \mathrm{~mA} \mathrm{~cm}^{-2}$ under a reverse bias of $0.2 \mathrm{~V}$.

We conduct the simulations of the tandem cell with different values of the tunnel junction doping levels. The optimum values of HOP bandgap energy and layer thickness mentioned above are used. The minimum doping level which leads to efficient tunneling effect and a good interconnection between top and bottom sub-cells is around $5 \times 10^{19} \mathrm{~cm}^{-3}$. This value corresponds to the degeneracy limit of the material: below this value, the silicon material is no longer degenerated on the conduction band side, leading to a weak overlap of conduction and valence bands and a poor band to band tunneling effect.

\subsection{Optimization of the HOP/silicon tandem-cell}

In this section we show that an optimum of the efficiency can be obtained for the HOP tandem cell by varying both the HOP absorbing layer bandgap and thickness. Indeed, starting from the optimized doping level of the TJ, we can optimize the complete tandem

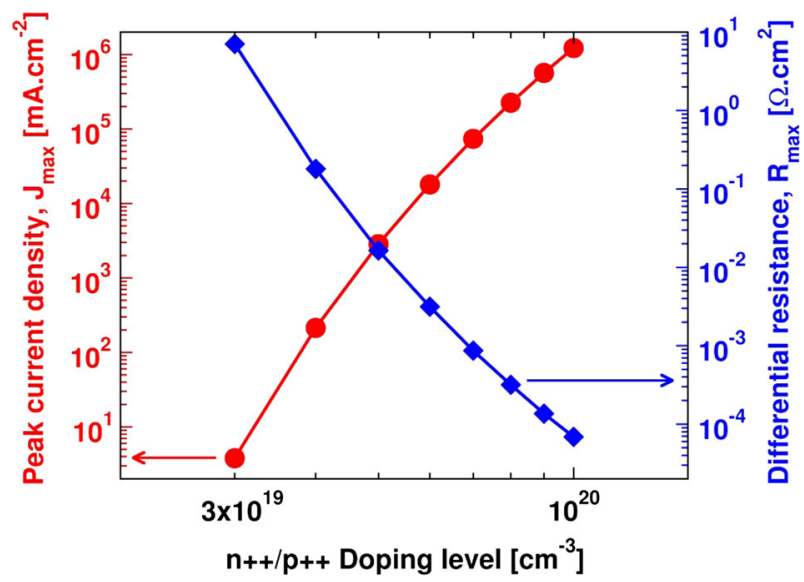

Fig. 5 Characteristic of the tunnel junction as a function of the doping level. The peak current density $\mathrm{J}_{\max }$ $\left(\mathrm{mA} \mathrm{cm}{ }^{-2}\right)$ and the differential resistance $R_{\max }\left(\Omega \mathrm{cm}^{2}\right)$ are marked by red circles and blue squares, respectively. (Color figure online) 


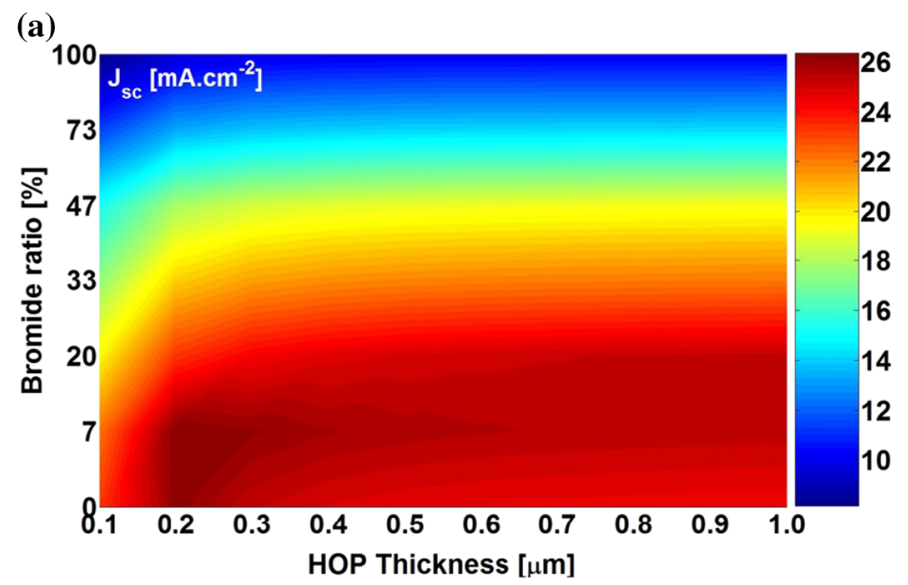

(b)

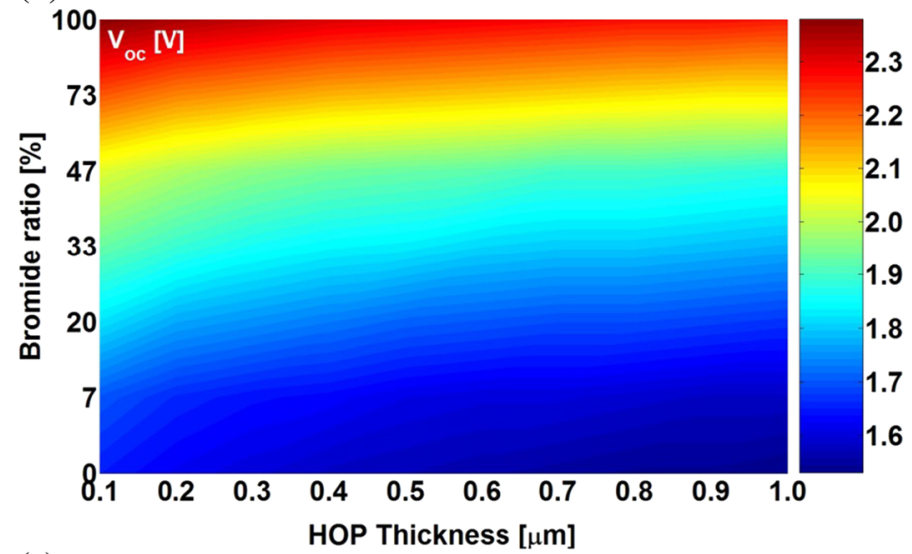

(c)

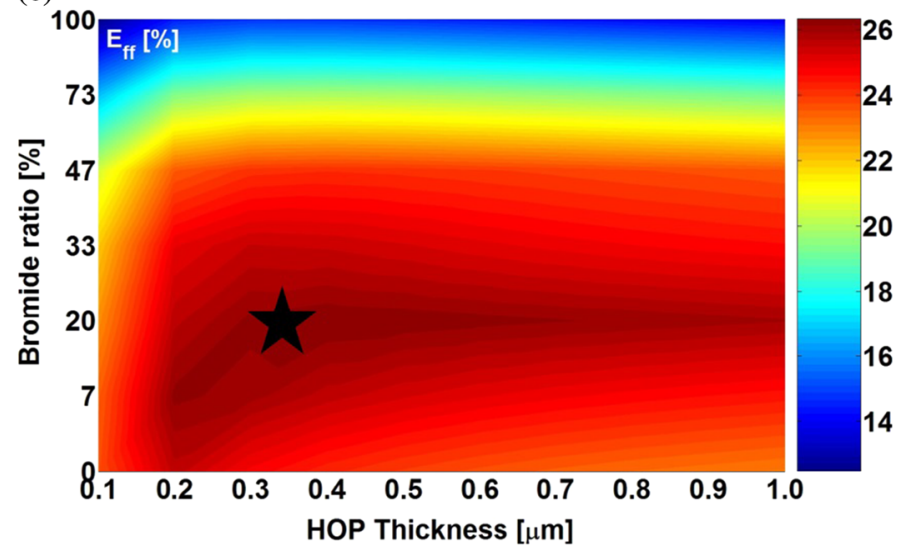

Fig. 6 Tandem cell a short-circuit current $J_{\mathrm{sc}}$, b open-circuit voltage $\mathrm{V}_{\mathrm{oc}}$, and c efficiency $\mathrm{E}_{\mathrm{ff}}$. The black star in c marks the maximum efficiency $27 \%$ obtained for a bromide ratio of $20 \%$ and a thickness of $350 \mathrm{~nm}$ 


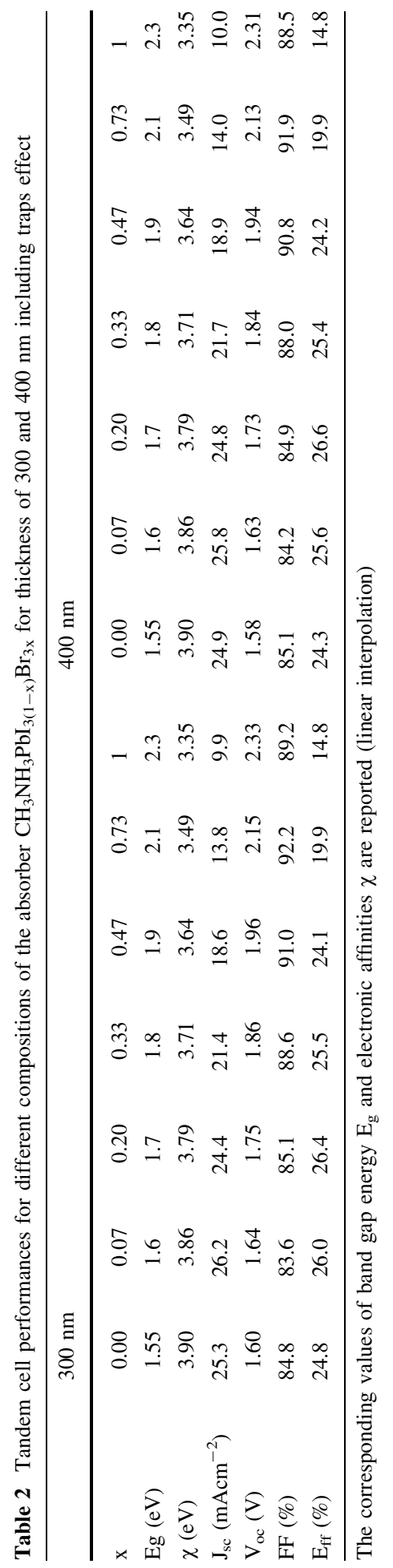


solar cell. Figure 6 shows the mapping of $\mathrm{J}_{\mathrm{SC}}, \mathrm{V}_{\mathrm{OC}}$ and $\mathrm{E}_{\mathrm{ff}}$ in a HOP/Si tandem cell as a function (1) of the bromide concentration in the absorbing layer, and (2) of its thickness.

For a fixed bromide concentration value $\mathrm{x}$, i.e. a given HOP bandgap energy, $\mathrm{J}_{\mathrm{sc}}$ increases as a function of the thickness up to $1 \mu \mathrm{m}$. However, a small decrease in $\mathrm{J}_{\mathrm{sc}}$ is noted for thicker absorbers likely due to carrier recombination effects. The trend of $\mathrm{V}_{\mathrm{oc}}$ variation as a function of the absorber thickness is a monotonous decrease whatever the value of the absorber bandgap energy. This is again due to the decrease of the electric field in the absorbing layer. This behavior is related to the balance between generation current in the absorber and the junction forward current. The cell efficiency presents an optimum value for each value of the absorber bandgap energy and with the parameters used in the present simulation, an optimum as high as $27 \%$, i.e. higher than the best silicon solar cell record (optimized HIT structure) (Masuko et al. 2014), is obtained for $\mathrm{CH}_{3} \mathrm{NH}_{3} \mathrm{PbI}_{3(1-\mathrm{x})} \mathrm{Br}_{3 \mathrm{x}}$ with a bromide concentration of $\mathrm{x}=0.2$, corresponding to a HOP bandgap energy of $1.7 \mathrm{eV}$, and a HOP absorber layer thickness between 300 and $400 \mathrm{~nm}$. Table 2 shows the computed values of $\mathrm{J}_{\mathrm{SC}}$ and $\mathrm{V}_{\mathrm{oc}}$, the filling factor (FF) and the cell efficiency for different halide compositions for top sub-cell absorbing layers with thickness of 300 and $400 \mathrm{~nm}$.

The maximum value obtained for $\mathrm{J}_{\mathrm{sc}}$ is about $26.2 \mathrm{~mA} \mathrm{~cm}{ }^{-2}$ for a HOP bandgap energy of $1.6 \mathrm{eV}$ and a $\mathrm{V}_{\mathrm{oc}}$ rising from $1.6 \mathrm{~V}$ to $2.3 \mathrm{~V}$ is observed for absorber bandgap energy from 1.55 to $2.3 \mathrm{eV}$. Moreover, we find a maximum plateau of the efficiency for an absorber thickness from 300 to $400 \mathrm{~nm}$. Thus, the alloy perovskite absorber with a bromide ratio of 0.2 and a thickness in the $300-400 \mathrm{~nm}$ range insures the best efficiency conditions of the whole tandem cell. Noteworthy, the ideal maximum conversion efficiency for a tandem cell with optimized absorbers band gaps for top and bottom cell, and without any recombination losses is $42.2 \%$. It gives an hint about the importance of recombination losses in a realistic situation by comparison to the maximum efficiency reported here $(27 \%)$.

\section{Conclusion}

In summary, the numerical simulation of a hybrid organic-inorganic perovskite on silicon tandem solar-cell using drift-diffusion modelling with traps recombination effect and including a tunnel junction has been performed. It is first shown that $5 \times 10^{19} \mathrm{~cm}^{-3} p$ and $n$ doping levels of $\mathrm{Si}$ are high enough to guarantee good enough tunneling properties in this device. From the simulations, the efficiency of the whole tandem device under AM1.5 illumination is derived and optimized with respect to the halide composition of the HOP materials and the thickness of the absorber layer. The optimum configuration is obtained for a perovskite thickness between 300 and $400 \mathrm{~nm}$ and a bromide concentration of $20 \%$, which corresponds to a bandgap energy of $1.7 \mathrm{eV}$.

The corresponding optimal photovoltaic efficiency of the tandem cell is equal to $27 \%$, showing that the perovskite methyl ammonium lead tri-iodide tri-bromide alloy $\mathrm{CH}_{3} \mathrm{NH}_{3} \mathrm{PbI}_{3(1-\mathrm{x})} \mathrm{Br}_{3 \mathrm{x}}$ or related alloys could be suitable candidates as absorbing materials to realize high efficiency and low cost silicon based tandem solar cells, provided that the problem of light-induced halide segregation is circumvented.

Acknowledgements The work in France was supported by Agence Nationale pour la Recherche (TRANSHYPERO and SUPERSANSPLOMB ANR projects). The work performed at FOTON and ISCR has received funding from the European Union's Horizon 2020 program, through a FET Open research and innovation action under the grant agreement No 687008. 


\section{References}

Albrecht, S., Saliba, M., Correa Baena, J.P., Lang, F., Kegelmann, L., Mews, M., Steier, L., Abate, A., Rappich, J., Korte, L., Schlatmann, R., Nazeeruddin, M.K., Hagfeldt, A., Grätzel, M., Rech, B.: Monolithic perovskite/silicon-heterojunction tandem solar cells processed at low temperature. Energy Environ. Sci. 9, 81-88 (2016)

Almosni, S., Robert, C., Nguyen, Thanh T., Cornet, C., Létoublon, A., Quinci, T., Levallois, C., Perrin, M., Kuyyalil, J., Pedesseau, L., Balochi, A., Barate, P., Even, J., Jancu, J.M., Bertru, N., Marie, X., Durand, O., Le Corre, A.: Evaluation of InGaPN and GaAsPN materiels lattice-matched to Si for multijunction solar cells. JAP 113, 1-16 (2013)

Bailie, C.D., Christoforo, M.G., Mailoa, J.P., Bowring, A.R., Unger, E.L., Nguyen, W.H., Burschka, J., Pellet, N., Lee, J.Z., Grätzel, M., Noufi, R., Buoassi, T., Salleo, A., McGehee, M.D.: Semi-transparent perovskite solar cells for tandems with silicon and CIGS. Energy Environ. Sci. 8, 956-963 (2015)

Ball, J.M., Stranks, S.D., Hörantner, M.T., Hüttner, S., Zhang, W., Crossland, E.J.W., et al.: Optical properties and limiting photocurrent of thin-film perovskite solar cells. Energy Environ. Sci. 8, 602-609 (2015)

Baudrit, M., Algora, C.: Modeling of GaInP/GaAs dual-junction solar cells including Tunnel Junction. In: 33rd IEEE Photovoltaic Specialists Conference 2008 PVSC ‘08, pp. 1-5 (2008)

Baudrit, M., Algora, C.: Tunnel diode modeling, including nonlocal trap-assisted tunneling: a focus on III-V multijunction solar cell simulation. IEEE Trans. Electron Devices 57, 2564-2571 (2010)

Blancon, J.C., Tsai, H., Nie, W., Stoumpos, C., Pedesseau, L., Katan, C., Kepenekian, M., Soe, C.M.M., Appavoo, K., Sfeir, M.Y., Tretiak, S., Ajayan, P.M., Kanatzidis, M.G., Even, J., Crochet, J.J., Mohite, A.D.: Extremely efficient internal exciton dissociation through edge states in layered 2D perovskites. Science 355, 1288-1292 (2017)

Burschka, J., Pellet, N., Moon, S.-J., Humphry-Baker, R., Gao, P., Nazeeruddin, M.K., et al.: Sequential deposition as a route to high-performance perovskite-sensitized solar cells. Nature 499, 316-319 (2013)

Bush, K., Palstrom, A.F., Zhengshan, J.Y., Boccard, M., Cheacharoen, R., Mailoa, J.P., McMeekin, D.P., Hoye, R.L.Z., Bailie, C.D., Leijtens, T., Peters, I.M., Minichetti, M.C., Rolston, N., Prasanna, R., Sofia, S., Harwood, D., Ma, W., Moghadam, F., Snaith, H.J., Buonassisi, T., Holman, Z.C., Bent, S.F., McGehee, M.D.: 23.6\%-efficient monolithic porovskite/silicon tandem solar celles with improved stability, Nature. Energy 2, 1-7 (2017)

Chen, Q., Zhou, H., Hong, Z., Luo, S., Duan, H.-S., Wang, H.-H., et al.: Planar heterojunction perovskite solar cells via vapor-assisted solution process. J. Am. Chem. Soc. 136, 622-625 (2014)

Chen, S., Zhu, L., Yoshita, M., Mochizuki, T., Kim, C., Akiyama, H., et al.: Thorough subcells diagnosis in a multi-junction solar cell via absolute electroluminescence-efficiency measurements. Sci. Rep. 5, 7836 (2015)

Coutts, T.J., Emery, K.A., Scott, Ward J.: Modeled performance of polycrystalline thin-film tandem solar cells. Prog. Photovolt. Res. Appl. 10, 195-203 (2002)

Dimroth, F.: High-efficiency solar cells from III-V compound semiconductors. Phys. Status Solidi C 3, 373-379 (2006)

Dimroth, F., Grave, M., Beutel, P., Fiedeler, U., Karcher, C., Tibbits, T.N.D., et al.: Wafer bonded fourjunction GaInP/GaAs//GaInAsP/GaInAs concentrator solar cells with 44.7\% efficiency. Prog. Photovolt. Res. Appl. 22, 277-282 (2014)

Durand, O., Almosni, S., Ping Wang, Y., Cornet, C., Létoublon, A., Robert, C., Levallois, C., Pedesseau, L., Rolland, E.J., Jancu, B.N., Le Corre, A., Mandorlo, F., Lemiti, M., Rale, P., Lombez, L., Guillemoles, J.-F., Laribi, S., Ponchet, A., Stodolna, J.: Monolithic integration of diluted-nitride III-V-N compounds on silicon substrates: toward the III-V/Si Concentrated Photovoltaics. Energy Harvest. Syst. 1(3-4), 147-156 (2014). https://doi.org/10.1515/ehs-2014-0008. (Special Issue Article. ISSN (Online) 2329-8766, ISSN 2329-8774)

Esaki, L.: New phenomenon in narrow germanium p-n junctions. Phys. Rev. 109, 603-604 (1958)

Filipič, M., Löper, P., Niesen, B., De Wolf, S., Krč, J., Ballif, C., et al.: $\mathrm{CH}_{3} \mathrm{NH}_{3} \mathrm{PbI}_{3}$ perovskite-silicon tandem solar cells: characterization based optical simulations. Opt. Express 23, A263-A278 (2015)

Friedman, D.J.: Progress and challenges for next-generation high-efficiency multijunction solar cells. Curr. Opin. Solid State Mater. Sci. 14, 131-138 (2010)

Geisz, J.F., Friedman, D.J.: III-N-V semiconductors for solar photovoltaic applications. Semicond. Sci. Technol. 17, 769-777 (2002)

Geisz, J.F., Friedman, D.J., Ward, J.S., Duda, A., Olavarria, W.J., Moriarty, T.E., et al.: 40.8\% efficient inverted triple-junction solar cell with two independently metamorphic junctions. Appl. Phys. Lett. 93, 1-3 (2008) 
Green, M.A., Emery, K., Hishikawa, Y., Warta, W., Dunlop, E.D., Levi, D.H., Ho-Baillie, W.Y.: Solar cell efficiency tables. Prog. Photovoltaics Res. Appl. 25, 333-334 (2016)

Hirst, L.C., Ekins-Daukes, N.J.: Fundamental losses in solar cells. Prog. Photovolt. Res. Appl. 19, 286-293 (2011)

Hörantner, M.T., Snaith, H.: Predincting and optimizing the energy yield of perovskite-on-silicon tandem solar cells under real world conditions. Energy Environ. Sci. (2017). https://doi.org/10.1039/ c7ee01232b. (accepted manuscript)

Im, J.-H., Jang, I.-H., Pellet, N., Grätzel, M., Park, N.-G.: Growth of $\mathrm{CH}_{3} \mathrm{NH}_{3} \mathrm{PbI}_{3}$ cuboids with controlled size for high-efficiency perovskite solar cells. Nat. Nanotechnol. 9, 927-932 (2014)

Jeon, N.J., Noh, J.H., Yang, W.S., Kim, Y.C., Ryu, S., Seo, J., et al.: Compositional engineering of perovskite materials for high-performance solar cells. Nature 517, 476-480 (2015)

Kojima, A., Teshima, K., Shirai, Y., Miyasaka, T.: Organometal halide perovskites as visible-light sensitizers for photovoltaic cells. J. Am. Chem. Soc. 131, 6050-6051 (2009)

Kurtz, S.R., Faine, P., Olson, J.M.: Modeling of two-junction, series-connected tandem solar cells using topcell thickness as an adjustable parameter. J. Appl. Phys. 68, 1890-1895 (1990)

Lee, M.M., Teuscher, J., Miyasaka, T., Murakami, T.N., Snaith, H.J.: Efficient hybrid solar cells based on meso-superstructured organometal halide perovskites. Science 338, 643-647 (2012)

Liu, M., Johnston, M.B., Snaith, H.J.: Efficient planar heterojunction perovskite solar cells by vapour deposition. Nature 501, 395-398 (2013)

Loper, P., Niesen, B., Moon, S.-J., MartindeNicolas, S., Holovsky, J., Remes, Z., et al.: Organic-inorganic halide perovskites: perspectives for silicon-based tandem solar cells. IEEE J. Photovolt. 4, 1545-1551 (2014)

Loper, P., Moon, S.J., Martin de Nicolas, S., Niesen, B., Ledinsky, M., Nicolay, S., Bailat, J., Yum, J.H., De Wolf, S., Ballif, C.: Organic-inorganic halide perovskite/crystalline silicon four-terminal tandem solar cells. Phys. Chem. Chem. Phys. 17, 1619-1629 (2015)

Mailoa, J.P., Bailie, C.D., Johlin, E.C., Hoke, E.T., Akey, A.J., Nguyen, W.H., et al.: A 2-terminal perovskite/silicon multijunction solar cell enabled by a silicon tunnel junction. Appl. Phys. Lett. 106, 1-4 (2015)

Masuko, K., Shigematsu, M., Hashiguchi, T., Fujishima, D., Kai, M., Yoshimura, N., et al.: Achievement of more than 25\%; conversion efficiency with crystalline silicon heterojunction solar cell. IEEE J. Photovolt. 4, 1433-1435 (2014)

Minemoto, T., Murata, M.: Device modeling of perovskite solar cells based on structural similarity with thin film inorganic semiconductor solar cells. J. Appl. Phys. 116, 1-6 (2014)

Minemoto, T., Murata, M.: Theoretical analysis on effect of band offsets in perovskite solar cells. Sol. Energy Mater. Sol. Cells 133, 8-14 (2015)

Noh, J.H., Im, S.H., Heo, J.H., Mandal, T.N., Seok, S.I.: Chemical management for colorful, efficient, and stable inorganic-organic hybrid nanostructured solar cells. Nano Lett. 13, 1764-1769 (2013)

Rolland, A., Pedesseau, L., Even, J., Almosni, S., Robert, C., Cornet, C., et al.: Design of a lattice-matched III-V-N/Si photovoltaic tandem cell monolithically integrated on silicon substrate. Opt. Quantum Electron. 46, 1397-1403 (2014)

Sadhanala, A., Deschler, F., Thomas, T.H., Dutton, S.E., Goedel, K.C., Hanush, F.C., Lai, M.L., Steiner, U., Bein, T., Docampo, P., Cahen, D., Friend, R.H.: Preparation of single-phase films of $\mathrm{CH}_{3} \mathrm{NH}_{3-}$ $\mathrm{Pb}\left(\mathrm{I}_{1-\mathrm{x}} \mathrm{Br}_{\mathrm{x}}\right)_{3}$ with sharp optical band edges. J. Phys. Chem. lett. 5(15), 2501-2505 (2014)

Sheng, R., Ho-Baillie, A., Huang, S., Chen, S., Wen, X., Hao, X., et al.: Methylammonium lead bromide perovskite-based solar cells by vapor-assisted deposition. J. Phys. Chem. C 119, 3545-3549 (2015)

Shockley, W., Queisser, H.J.: Detailed balance limit of efficiency of p-n junction solar cells. J. Appl. Phys. 32, 510-519 (1961)

Silvaco Inc.: ATLAS User's Manual. Sunnyvale, CA (2012) http://silvaco.com

Snaith, H.J.: Perovskites: the emergence of a new era for low-cost, high-efficiency solar cells. J. Phys. Chem. Lett. 4, 3623-3630 (2013)

Stranks, S.D., Eperon, G.E., Grancini, G., Menelaou, C., Alcocer, M.J.P., Leijtens, T., et al.: Electron-hole diffusion lengths exceeding 1 micrometer in an organometal trihalide perovskite absorber. Science 342, 341-344 (2013)

Tsai, H., Nie, W., Blancon, J.-C., Stoumpos, C.C., Asadpour, R., Harutyunyan, B., Neukirch, A.J., Verduzco, R., Crochet, J.J., Tretiak, S., Pedesseau, L., Even, J., Alam, M.A., Gupta, G., Lou, J., Ajayan, P.M., Bedzyk, M.J., Kanatzidis, M.G., Mohite, A.D.: High-efficiency two-dimensional RuddlesdenPopper perovskite solar cells. Nature 536, 312-316 (2016)

Yang, W., Yao, Y., Wu, C.-Q.: Mechanism of charge recombination in meso-structured organic-inorganic hybrid perovskite solar cells: a macroscopic perspective. J. Appl. Phys. 117, 1-10 (2015) 